Winter 1998

\title{
The World Would Do Better to Ask Why is Frimbo Sherlock Holmes?: Investigating Liminality in Rudolph Fisher's The Conjure- Man Dies
}

Adrienne Gosselin

Cleveland State University, a.gosselin@csuohio.edu

Follow this and additional works at: https://engagedscholarship.csuohio.edu/cleng_facpub

Part of the African American Studies Commons, American Literature Commons, and the Literature in English, North America Commons

How does access to this work benefit you? Let us know!

Publisher's Statement

This article first appeared in African American Review, vol. 32, no. 4, 1998, pp. 607-619. www.jstor.org/stable/2901240.

\section{Original Published Citation}

Gosselin, Adrienne Johnson. "The World Would Do Better to Ask Why Is Frimbo Sherlock Holmes?:

Investigating Liminality in Rudolph Fisher's The Conjure-Man Dies." African American Review, vol. 32, no. 4, 1998, pp. 607-619. www.jstor.org/stable/2901240.

This Article is brought to you for free and open access by the English Department at EngagedScholarship@CSU. It has been accepted for inclusion in English Faculty Publications by an authorized administrator of EngagedScholarship@CSU. For more information, please contact library.es@csuohio.edu. 
The World Would Do Better to Ask Why is Frimbo Sherlock Holmes?: Investigating Liminality in Rudolph Fisher's The Conjure-Man Dies

Author(s): Adrienne Johnson Gosselin

Source: African American Review, Vol. 32, No. 4 (Winter, 1998), pp. 607-619

Published by: Indiana State University

Stable URL: http://www.jstor.org/stable/2901240

Accessed: 10-03-2017 16:57 UTC

JSTOR is a not-for-profit service that helps scholars, researchers, and students discover, use, and build upon a wide range of content in a trusted digital archive. We use information technology and tools to increase productivity and facilitate new forms of scholarship. For more information about JSTOR, please contact support@jstor.org.

Your use of the JSTOR archive indicates your acceptance of the Terms \& Conditions of Use, available at http://about.jstor.org/terms

Indiana State University is collaborating with JSTOR to digitize, preserve and extend access to African American Review 


\section{The World Would Do Better to Ask Why is Frimbo Sherlock Holmes?: Investigating Liminality in Rudolph Fisher's The Conjure-Man Dies}

\author{
"But what on earth does it really matter who killed Frimbo-except to \\ Frimbo?" \\ They stood a moment in silence. Presently Frimbo added in an almost bitter \\ murmur: "The rest of the world would be better to concern itself with why Frimbo \\ is black." (Fisher, Conjure-Man 230)
}

$\mathrm{T}$ he above exchange is generally considered to be the larger mystery of Rudolph Fisher's The Conjure-Man Dies, published in 1932 at the end of the Harlem Renaissance. Written two years before Fisher's death, The Conjure-Man Dies is the first non-serialized detective novel by an African American to use a black detective figure and the first in the genre to use multiple detectives. ${ }^{1}$ Structured in the mode of classical detective fiction, the story begins when Dr. John Archer, a pedantic physician with a penchant for solving crimes, is summoned from his home by Bubber Johnson, an ex-sanitation worker turned private investigator, to examine the body of N'Gana Frimbo, the African conjure-man who lives above the mortuary across the street from Archer. Archer pronounces Frimbo dead and instructs Bubber and Bubber's partner Jinx Jenkins (the last person to see Frimbo alive) to carry the body downstairs to the mortuary until the police arrive. Heading the police investigation is Perry Dart, one of ten black men on the Harlem police force and the only one to be promoted to detective. Archer and Dart search Frimbo's apartment, revealing the victim to have been "no ordinary fakir" but a Harvard graduate and amateur scientist who has a fully equipped laboratory filled with jars of preserved biological specimens, including one Archer identifies as "male sex glands." The investigation proceeds with the interrogation of five suspects, one of whom is the wife of Stanley Crouch, Frimbo's landlord, whose mortuary occupies the first floor of the building. Although not a suspect, Crouch returns for some late night work, is questioned by Dart, and subsequently dismissed. Just as the crime and clues phase of the investigation seems to be ending, however, the body is discovered missing from the mortuary, prompting a second search. After Dart reassembles the suspects in the interrogation room, the room goes suddenly black. When the lights come up again, Frimbo is alive, seated in the same chair in which Archer examined the presumably missing corpse. Unable to convince police that, as the "corpse," he had been not dead, but in a state of suspended animation, Frimbo joins Archer and Dart in the search for his would-be murderer. Never convinced by Frimbo's story, Archer and Dart discover that the murdered man is $\mathrm{N}^{\prime} \mathrm{Ogo}$ Frimbo, N'Gana Frimbo's servant and fellow countryman, and attempt to prove the conjure-man to be the servant's murderer. In
Adrienne Johnson

Gosselin is Assistant Professor of Literature at Cleveland State University; editor of Murder From the Other Side, an anthology on multicultural detective fiction; and author of The Last New Negro, a novel about African American soldiers in the First World War. She wishes to thank Arlene Elder, Donna Phillips, and the reviewers of African American Review for the careful readings of earlier versions of this essay. 
the solution phase of the investigation, Frimbo reveals the servant's murderer to be Stanley Crouch, but only as Crouch succeeds in committing the murder originally intended and kills N'Gana Frimbo for having an affair with his wife.

Certainly, as a Harlem conjureman who is also an African king, graduate of Harvard, student of biology, psychology, and deterministic philosophy, and reader of such books as Tankard's Determinism and Fatalism, Bostwick's The Concept of Inevitability, and Fairclough's The Philosophical Basis of Destiny, the character of N'Gana Frimbo qualifies as a cultural enigma. Such figures are generally read in terms of binary conflict, and Frimbo is no exception. Stephen Soitos, for example, sees Frimbo as a representation of a cultural struggle among African Americans (97), while Helen Lock suggests that Frimbo's death at the end of the novel implies that the struggle his character embodies is ultimately won by the "forces ... of Western discourse" (46). And although Soitos recognizes the ability of the Afrocentric world view to achieve synthesis of dualities, he nonetheless concludes that, while "Frimbo's positive role in solving the mystery and Archer's unreserved admiration of the man both suggest that a meld of Afrocentric and EuroAmericentric views might be possible ... the real murder of N'Gana Frimbo in the last pages of the novel counters this speculation with cold, negative reality" (116). For Soitos and Lock, the "cold, negative reality" is the inability of an Afrocentric world view to maintain its own in the face of European culture, an inevitable conclusion when the character is read in terms of binary struggle. Binary logic, however, limits interpretation to either/or propositions and fails to reconcile what I argue to be some of the novel's more important liminal moments. On the other hand, nonbinary sleuthing can go where binary logic fears to tread, in this case to reveal the novel's ratiocinative detective to be not the pedantic Dr. Archer, but N'Gana Frimbo himself, thus exposing Rudolph Fisher as the perpetrator of one of the most dastardly crimes in popular fiction since "The Final Solution" - the murder of Sherlock Holmes.

A ccording to Stephen Knight, the Holmesian detective has achieved universal recognition in that "no literary figure has a stronger hold on the public imagination than Sherlock Holmes. The name is a synonym for a detective; he has been parodied, imitated and recreated in all media with great success." Knight's sociological study of crime fiction locates the reason for Holmes's "embarrassing success" in the character's ability to calm the anxieties of a readership that "had faith in modern systems of scientific and rational inquiry" but felt a lack of such power themselves (67). For Knight, Doyle's achievement lies in the construction of fables about a "problem-solving hero who works in a recognizable world with essentially graspable and credible rational methods" (78). As an artistic creation, the heart of Doyle's success rests in Holmes's ability to offer a middle-class reading public a means of psychic protection in the frame of a superior ratiocination that embodied both the essential conservatism and patronizing autocracy inherent in the Victorian notion of rational individualism.

In Knight's analysis, Doyle's construct of rational individualism has two premises: "the rational scientific idea that events are really linked in an unaccidental chain, and the individualistic notion that a single inquirer canand should-establish the links" (68). Both premises resonate in Frimbo's explanation of "applied determinism," which he alone," as a being of another order," has the power to comprehend (Fisher 228). As Frimbo explains to 
Archer, the power enables him to act upon the "events linked in an unaccidental chain" that occur in people's lives without upsetting their order:

\begin{abstract}
"It is thus I am able to be of service to those who come to me. I act upon their lives. I do not have to upset their order. I simply change the velocity of what is going on. I am a catalyst. I accelerate or retard a reaction without entering into it. This changes the cross currents.... A husband reaches home twenty minutes too soon. A traveler misses his train-and escapes death in a wreck. Simple, is it not?" (228).
\end{abstract}

Even the phrasing of Frimbo's final question - "'Simple, is it not?' "reflects the Holmesian tendency to popularize rational individualism. Indeed, as Knight points out, Doyle's ability to popularize and, even more importantly, naturalize rational individualism is central to Sherlock Holmes's appeal (68). Holmes's use of comments as simple as "to put it mildly," or even the signature "elementary, my dear Watson," serve to demystify ratiocination, becoming in Knight's opinion "game language to make unethical faith in this ideology seem both pleasant and natural" (68). And while Frimbo's revelation leaves Archer speechless for the only time in the novel, the difference between Archer and Frimbo as "men of science" begins to dawn: Frimbo begins to emerge as a heightened version of Archer's own ambitions, illustrated later by the instruments in Archer's lab, which, unlike Frimbo's, are "mostly virgin" and "only a fraction of what Frimbo has" (197). In this light, Frimbo can be seen to embody the ideology of "personal achievement and personal morality" which Knight finds indigenous to the Holmesian detective (95). As the man of science who embraces rational individualism, Frimbo does indeed conduct a service by changing the velocity of events in the lives of the Harlem community, but unlike Archer, who sees only two patients during the course of the novel- "The first pleaded a bad cold and got his liquor prescription, the second pleaded hard times and borrowed three dollars" (197) Frimbo is well paid for the services he provides. As a result, he can afford his passion for scientific research, if only because, as Dart points out, in Harlem "a racket like fortune telling" was probably a "better racket than medicine" (27).

The qualities of rational individualism were made physically recognizable by Sidney Paget's illustrations of Sherlock Holmes, so much so that Doyle altered his earlier description of Holmes to fit Paget's "authoritative version" (Knight 84). Like Holmes, Frimbo's appearance is distinctive and dramatic in appearance. He enters the novel as a "deep strong voice in the middle of the death room" (168), seated in the very chair in which he was supposed to have been murdered. Lights come up in the darkened room to reveal "a black man wearing a black robe and a black silk head-band; a man with fine, almost delicate features, gleaming, deep-set black eyes, and an expression of supreme intelligence and tranquility" (169). Like Holmes, Frimbo is a "self-confessed Bohemian" (Knight 80) and, also like Holmes, a man of independent means. As a king, as a successful conjure-man, and as a gambler who consistently "hits" the numbers for five thousand dollars a week, Frimbo, again like Holmes, lives comfortably in, but will "not be enclosed by, the world of bourgeois professionalism" (Knight 79). And while Holmes surpasses the ratiocinative abilities of his predecessor by possessing a "greater variety of . . . miraculous powers" (Cawelti 82), Frimbo surpasses Holmes in that making miracles is Frimbo's occupation, as demonstrated by Lem Gassoway who, under Frimbo's psychic protection, survives an otherwise fatal knife wound to the head.

As a Holmesian detective, Frimbo shares a number of characteristics with other detectives derived from the Dupin-Holmes tradition. George Grella, for example, notes that, whatever their individual differences, detec- 
tives of this genre are recognized as "pronounced eccentrics, enjoying odd hobbies, interests, or life styles and frequently indulging in ... 'solitary oral vices' of eating, drinking, smoking, and boasting" (36). Feminine company, Frimbo tells Archer is " 'necessary to comfort, like blowing one's nose,' " but the study of biochemistry is "vital" to his existence (268). Beyond eccentricities, however, the Holmesian detective must possess a mind "blessed with penetrating observation, highly developed logical powers, wide knowledge, and a brilliantly synthetic imagination" (Cawelti 36), characteristics which Frimbo embodies.

And while Lock argues that Frimbo's metaphysical abilities grant him "the vision to see the murderer's identity" (47), the impetus behind Frimbo's "vision" is actually a variation of the ratiocinative process of "deduction" perfected by Doyle in the early Holmes novellas. Frimbo's solution to the servant's "calculable" murder echoes Holmes's use of "deductive reasoning," whose methodology Doyle provided in chapters titled "The Science of Deduction," which appeared at the end of the earlier works. Although a misapplication of the term science-and no more than a "set of fairly simple procedures within an aura of elaboration" (Knight 85-86) - the strategy established deduction as a scientific means of ordering the confusion required by the detection formula.

Beginning with Poe's Dupin, detachment has been another important characteristic of the ratiocinative detective, used to express what Poe termed the "ideality" that informs the "peculiar analytic ability" distinguishing the detective from the mere factual observer. Tracing the trope to differences between Poe and Samuel Coleridge on the nature of "reason," Knight explains:

Where Coleridge based "reason" in Christian intuition, Poe rests his "analysis" on imaginative power, operating with intellect and feeling combined at full strength. Poe probably drew the term "ideality" from the new psuedo-science of phrenology, where it meant 'the imaginative faculty' or 'the poetical faculty': it conveniently expresses both the mentalism and the basically idealist unreality of the area where Poe's hero is specially gifted. (40)
The ConjureMan Dies moment of cultural liminality.
Yet while Holmes embodies the analytic ability that characterizes Dupin, he never withdraws into his predecessor's idealist intellectualism. As a result, unlike Dupin, the Holmesian detective articulates a duality of the material and the ideal, the familiar with the exotic,

the need for isolation with the need for normal contact-dualities Frimbo shares with Holmes. Both characters live in rooms that reflect their scientific interests, yet rooms that, for all their eccentricities, are "cosy [and] filled with masculine gadgets for comfort (Knight 80). Neither is a hermit, nor is either attached, and both share lodgings-Holmes with Watson and Frimbo with his servant. Like Holmes, Frimbo engages in disguise, posing as the servant, and like Holmes, works alone in that it is the servant who sits with clients while Frimbo remains in another room viewing clients through a television lens. As well as an aspect of character, detachment is also an element of formal structure, one which enables investigation to be narrated from a perspective that sees but does not participate in the Holmesian detective's process of reasoning. As John Cawelti notes, "If he uses the detective's point of view, the writer has trouble keeping the mystery a secret without creating unnatural and arbitrary limits on what is shown ... of the detective's reasoning process" (83). While the device of the Watson-like figure as the narrative point of view is the usual strategy in classical detective fiction, The Conjure-Man Dies uses dual lines of inquiry, thus enabling 
Fisher to manipulate Frimbo as the detached detective by focusing on the false line of inquiry followed by Archer and Dart, a strategy that further supports the illusion of Dr. Archer as the ratiocinative detective with the superior mind.

$\mathrm{n}$ an inscription to Carl Van

Vecthen, Fisher describes The Conjure-Man Dies as an "experiment with technique" (Tignor 17), and while Fisher's experimentation involves a number of strategies associated with detection schemes, this reading focuses on the formal principle of mystification, whose balance with inquiry is fundamental to the classical detective formula. In his study of genre and popular fiction, Cawelti explains that the proper balance between inquiry and mystification depends on the author's ability to invent some new type of mystification while still working within the conventional structure of classical detection. In the early short story form, Cawelti notes, the story of classical detection focused more on "inquiry," but as writers began to develop longer and more complex stories, there was a need to find ways of resolving the tension between detection and mystification. The solution was to place the detective at the center and add a range of other interests such as "character, action, setting, local color, or assorted bits of information" in order to "flesh out ... the bare bones of the inquiry structure" (Cawelti 110). In this sense, if mystification depends on the author's ability to invent some new type of mystification without distracting from investigation, then one of the ways in which Fisher fleshes out the bare bones of inquiry is with notions of primitivism, one of the most controversial topics straddling the axis between modernism and the Harlem Renaissance.

In order to appreciate the ramifications of Fisher's experiment with prim- itivism and mystification, one needs to understand that, in the African American literary tradition, the modernist obsession with primitivism exemplifies what Henry Louis Gates would call a moment of literary liminality in which black America and white America face each other in a "paradox of ideological confrontation" (72). For example, while for white modernists "The Negro" was the central metaphor for the "uncorrupted remnant of preindustrial man" (Stoff 127), black modernists saw this representation as a "jazzed-up version of the 'contented slave' " (Sterling Brown, qtd. in McCluskey xviii). And while images spawned by Eurocentric theories of primitivism led to the modernist "white cult of the primitive" (Worth 470 ), these same theories led to distinctions between "high" and "low" culture held fast by the older Harlem Renaissance intelligentsia, advocates of black nationalism and racial uplift, the two ideologies dominating the African American intellectual community in the years between post-Reconstruction and the end of the First World War. Following the war, however, younger black intellectuals-Rudolph Fisher among them-felt that, as products of higher education, it was their responsibility to move beyond such delineations in order to depict a "truer synthesis of black culture" (McCluskey xii), one that included the forms and expressions of folk culture while steering clear of (white) exotica and (black) oversentimentality.

As George Kent observes, the educational background and "symbols of middle-class respectability" gave younger Renaissance intellectuals a "psychological poise ... from which they could not easily be overawed by definitions of black realities provided by American and Western culture" (36). ${ }^{2}$ Kevin Gaines concurs, noting that, unlike the older intellectuals, black modernists "were the product of a new historical conjuncture heading into the Depression era, characterized by white violence and southern intran- 
sigence, certainly, but also several forms of interracial cooperation. These included the convergence of New Negro militancy and cultural radicalism, a growing alliance between blacks and white left-wing activity" (236). As a result, while older Harlem intellectuals such as W. E. B. Du Bois used folklore as a "flight from the pejorative racial connotations of . . . the urban setting" (Gaines 185-86), younger intellectuals such as Fisher and Langston Hughes used folklore in urban settings to rethink race and class and arrive at a truer definition of black culture. ${ }^{3}$

One factor accounting for differences in their approaches to folklore can be found in differences in attitude toward academic theories of folklore, theories which viewed folk culture from a "larger nineteenth century European worldview, a worldview which favored romanticism and primitivism" (Dundes, qtd. in Tracy 13). As Steven Tracy explains, "By primarily associating folklore with the past, by seeking the oldest versions of particular works of folklore as if they were the most complete and 'authentic,' and by collecting folklore with the attitude that it must be preserved before it is gone, some folklorists have implied that folklore is at least static, if not devolutionary ... suggesting that folklore is at least unchanging in a changing world, increasingly anachronistic and irrelevant to contemporary concerns" (14). At the same time, while academic theory held folklore as devolutionary and fragmented, urban folklorists such as Fisher and Hughes recognized that "the folklore that the (primarily white) critics labeled a survival of the primitive past was in fact being used and modified every day" (Tracy 14). Moreover, while academic theory held that the removal of folk material from its original source presented questions of perspective and authenticity, Fisher and Hughes recognized that a "Northern urban community made up of formerly Southern rural inhabitants is still a community, and what they make of their lore is still lore" (Tracy 15).

As Soitos's detailed analysis demonstrates, folk material-speech, sayings, songs, religion, superstitions, signs, and symbols-is central to The Conjure-Man Dies, used not only to flesh out the bare bones of inquiry, but to frame the plot as well. While the mystery itself centers on the murder, resurrection, and re-murder of N'Gana Frimbo, the novel's plot moves forward according to the folk sign "Death on the Moon," which foretells three deaths, each of which is witnessed by Bubber Johnson, the reader of the sign. Moreover, Fisher's use of double voice-described by Bernard Bell as an "ambivalent, laughing-to-keep-fromcrying perspective toward life as expressed in the use of irony and parody in Afro-American folklore and formal art" (xvi)-demonstrates Fisher's ability as an urban folklorist. The interview with the no-nonsense Aramentha Snead, for example, signifies on the migration of black Southern immigrants by capitalizing on the psychological shift from rural disfranchisement to urban pluralism: Detective Dart says to Snead, "'You're an American, of course,' " to which the woman replies, "I is now. But I originally come from Savannah, Georgia' " (Fisher 80).

At the same time, Fisher's decision to frame his interrogation of primitivism in a genre relegated to "entertainment" was not without risk. In fact, the novel was ignored by surveys of African American literature until 1987 (Bell), while critical articles, in keeping with the parameters of Arthur Davis's 1932 review, have focused on the work solely as "standard" detective fiction. Other critics question Fisher's strategy as catering to white primitivism (Lock 44 ) or claim the novel's interest to be "its overworking of Amos ' $n$ ' Andy dialogue to white (and, secretly, black) readers" (Lewis 275). And yet, Fisher's portrait of Africa not only circumvents the exotic primitive, but draws upon information from the four Pan-African 
Congresses convened by Du Bois between 1919 and 1927, as well as pioneer studies in African and African American history by Du Bois and Carter G. Woodson. Such information is utilized to create a believable world, a hypothetical Africa constructed of "conceivable possibilities" in the sense that believable means "recognizable as world, as person, as event" (Wright 66$67)$. Once recognizable, these abstracted possibilities become the basis for whatever personal involvement or identification the reader may feel-a dynamic that explains why historical accounts are often more vivid when conventions of fiction are employed (Wright 67-68).

Fisher's presentation of Buwongo "makés form visible" by creating a matrix of recognizable elements in the prosperous African nation over which Frimbo reigns as king. Here is a country that functions in a recognizable hierarchy with recognizable politics and recognizable social systems. The description of the village of Kimalu reveals a society with civil laws, as well as one with a system of local and national taxation. Moreover, as king of a country with more than one million inhabitants, Frimbo cannot be reduced to "tribal leader" and, as king, assumes a privilege recognizable as behavior accorded those born to the divine right of the monarchy.

Fisher's experimentation with form, like that of his white counterparts, occurs at a point in literary history at which fiction, in particular, is "marked by a prevalent style of perception and feeling"; as such-again, like his white counterparts-Fisher's modernity "consists in a revolt against this prevalent style" (Howe 13). The style against which Fisher as a black modernist is reacting is that of sentimentalism and social melodrama, the style embraced by so-called black Victorians in their attempts to disseminate images of civic and social behavior following Reconstruction (see Carby, Tate). And while the appropriation of Victorian gentility by blacks during the years of post-Reconstruction is one of the more liminal moments in African American history, as Claudia Tate points out, white America's adoption of Victorian gentility as a cultural value while violating the human rights of black people is liminal in itself (59). Understanding black modernism and its revolt against the prevalent style dominating black literature requires an understanding of Reconstruction and its deterioration, which in turn requires a concomitant awareness (1) that Victorian society was the dominant hegemony into which African Americans were emancipated and (2) that the values inherent in Victorian gentility (particularly moral rectitude and the patriarchal family structure) were used by both racial uplift and black nationalism to refute retrogressionism, the racist ideology espoused by white radical conservatives in both the North and South responsible for reversing what few political and economic gains blacks achieved under Reconstruction. ${ }^{4}$

The consequences of retrogressionism were extensive and far-reaching. The more obvious effects were seen in images of everyday life-calenders, pot holders, and playing cards that depicted black culture as intellectually inferior and black people as "lazy, ugly, intemperate, slothful, lascivious, and violent, indeed bestial" (Tate 10). Less obvious was its effect on academic scholarship, which, as noted above, contributed to notions of romanticism and primitivism in academic theories of folklore, and which influenced older black intellectuals in their attempts to define black culture. This impulse is best reflected in Du Bois's approach to the spirituals, which he sought to develop along the lines of the Volkgeist of German nationalism. For Du Bois, spirituals were representations of "high" black culture. Drawing on the African American and Judeo-Christian tradition, they became, in Du Bois's paradigm, a collective testament to a "faith in the ultimate justice of things ... that sometime, somewhere, men 
will judge men by their souls and not by their skins" (186). By emphasizing spirituals as the "folkloric and musical expression of African Americans' racial soul," Du Bois equated the form with German romanticism, a strategy that served a multiple purpose by creating an international context for black culture as it strengthened claims of cultural autonomy (Gaines 185). At the same time, alignment with the Volkgeist of German nationalism separated the spirituals from the blues, ragtime, and other varieties of popular music, such as minstrelsy, thus reinforcing uplift's notion of "high" versus "low" art.

Another product of nineteenthcentury academic theory is the trope of double-consciousness which, as Gaines observes, lends itself as a metaphor for educated blacks in that it "describes Du Bois's struggle, and that of other black elites, to transform a pejorative concept of race into an affirming vision of cultural distinctiveness" (9). "Tate points out that the theory of doubleconsciousness is the result of Du Bois's decision to turn from the "philosophic to the social sciences," and she traces the trope itself to a combination of Du Bois's interest in "the soul of different human races" and his later "racialized version of Hegelian dialectics," a decision Du Bois himself credits to William James and Albert Bushness Hart (Tate 275-76). Du Bois coined the concept of "two-ness" in "Strivings of the Negro," an article published in Atlantic Monthly and one of nine eventually revised to become the five essays comprising The Souls of Black Folk (Gilroy 124). The now familiar quote expresses the particular alienation of Americans of African descent: "One ever feels his two-ness,- - an American, a Negro; two souls, two thoughts, two unreconciled strivings; two warring ideals in one dark body, whose dogged strength alone keeps it from being torn asunder" (3).

Thus, double-consciousness as a trope becomes a moment of cultural liminality both in its intellectual dependence on white ideologies and white constructions of blackness, and in the black elite's perception of itself as middle-class while being denied that status by the very community being used to define it. From this perspective, Gaines finds the notion of double-consciousness ironic in its expression of a middle-class ideology without an actual middle class. His observation bears repeating in full:

Occupations within the black commu-
nity widely perceived by historians as
middle-class, including that of teacher,
minister, federal officer, businessman,
and professional, cannot be regarded
as equivalent with the business, man-
agerial, and craft labor occupations
among whites from which blacks were
largely excluded. The same applies to
the occupations that blacks held to ser-
vice white clienteles throughout the
late nineteenth century in the urban
North and South, such as barbering,
catering, and other personal service
and domestic jobs. Calling these ser-
vice occupations middle-class intro-
duces a false universal standard for
class formation that ignores the extent
to which the very notion of the black
middle class-indeed, of class itself-is
built on shifting ideological sands. (14)

In The Conjure-Man Dies, Stanley Crouch becomes the locus of Fisher's interrogation of the effect of Victorian middle-class ideology on the black community. Although as a black community Harlem released new black professionals from dependence on white clientele, the Victorian standards for class formation were nonetheless appropriated. Crouch is described as a "genial businessman on whom it would be difficult to play tricks," while his manner indicates that it is his right as landlord "to know just what had come about and how" (85). He is a member of the Forty Club, a private establishment which is patronized by other members of Harlem's nouveau riche, including Sy Brandon, one of Harlem's racketeering bosses Crouch offers as an alibi for the time of Frimbo's death. Crouch epitomizes the direction of the black middle class by the 1920s. No longer grounded in equal marriage or moral rectitude, the new black middle class is increasingly mate- 
rialist, having fully appropriated the values of the petit bourgeois.

Pampered and suitably bored, Martha Crouch is depicted as Crouch's possession. As Crouch explains to Dart, "'You know how women are-if they haven't anything much to do they get restless and dissatisfied. We haven't any kids and she has a girl to do the housework' " (87). To counteract her boredom, Martha Crouch collects the rent from Crouch's tenants, a pastime that leads to the affair with Frimbo.

Archer describes Crouch as " hard as a pawnbroker, with an extraordinarily keen awareness of his own possessions,' " (93) and in spite of the fact that Frimbo is the " "goose that laid golden eggs" " (92), it is this sense of possession that leads Crouch to murder Frimbo. Yet, with characteristic objectivity, Fisher refuses to condemn Crouch for his possessive nature. Instead, through Crouch's character, Fisher warns of the consequences of blindly adopting middle-class values in the same manner that the pathetic Doty Hicks is used to warn against drugs or the death of the numbers runner is used to reveal the dark side of "policy." In fact, Dart sees Crouch's callous reaction to Frimbo's death-" '. . . at least he didn't die in our debt' " (88) as a matter of self-preservation. Nor does the text condemn Crouch for murder; indeed, at the novel's conclusion, Bubber comments to Jin $x$ that Crouch " 'jes' didn't mean to lose his wife and his life both. Couldn't blame him for that'" (316).

Like racial uplift ideology, black nationalist discourse, identified in organizations such as Marcus Garvey's United Negro Improvement Association (UNIA), also typified Victorian sensibility and associated urban poverty with pathology and immorality. Black nationalist intellectuals comprised what Gaines calls a "nationalistic circle of intellectuals" (103), whose membership, along with Du Bois, included such pan-African intellectuals as Duse Mohammed Ali, editor of the African Times and Orient
Review, a London-based anti-colonial periodical; Anna J. Cooper; Archibald Grimké; Alexander Crummell; Alain Locke; Pauline Hopkins, author of $O f$ One Blood, the first serialized detective novel by an African American; and John Edward Bruce, founder of the Negro Society for Historical Research and author of The Black Sleuth, the second serialized detective novel written by an African American. Membership also included William $\mathrm{H}$. Ferris, editor of the UNIA's Negro World from 1919 to 1923, who is of particular significance to this reading of The ConjureMan Dies not only because his writings and career exemplify what Gaines sees as an "intersection of black nationalism and racial uplift ideology" (101-02), but because Ferris himself can be seen as a model for N'Gana Frimbo, embodying the authoritarian aspects against which the novel reacts.

Convinced that history was made by great men, Ferris, like other black nationalists, saw black (male) elites as the saviors of the race. Like Garvey, Ferris applied Darwinian notions of race survival to African American destiny and framed its rhetoric in all-ornothing terms of survival and manliness. But, as Gaines points out, while Garvey "simply inverted racial hierarchies to assert black civilization, pride, and power," Ferris "associated civilization with power, mastery, manhood, and the Anglo-Saxon" (102). For Ferris, who considered himself a radical in his opposition to Booker T. Washington, assimilation signified an "indispensable environmental process of acculturation" whereupon blacks absorbed the ideals and values of Western civilization in order to achieve the goal of black statehood and master for themselves "the 'Anglo-Saxon' mysteries of military, financial, technological, and economic power" (Gaines 104). 6

Educated at Yale and Harvard, Ferris, like the advocates of racial uplift, equated patriarchal ideals with freedom, and Ferris was equally convinced of the academic theories of urban pathology which held the condi- 
tions of poor blacks to be the result of "suspect morals" and "lack of cultural refinement." For Ferris, the injustice was in meting out "the same kind of treatment to the high Negro that should be meted out to the low" (qtd. in Gaines 104), and, in what Gaines terms a "severe case of double-consciousness," Ferris went so far as to propose the term Negrosaxon, with the intention of distinguishing black intellectuals from the pejoratives he perceived as being associated with "Negro" alone (104). In N'Gana Frimbo, one sees the ideals of Ferris's Negrosaxon- "disinterested black leadership, philosopher-king in ebony, unfettered by social constraints" (Gaines 104)-while in Ferris one sees Soitos's description of N'Gana Frimbo as "one of the more brilliant and confused blacks in modern detective literature" (97). Indeed, Soitos's suggestion that, with Frimbo's death, Fisher "perhaps ... implies that the burden of the African American double-conscious dilemma can result in self-destruction due to the sheer difficulty of achieving equilibrium" (111) reflects the cultural schizophrenia inherent in Ferris's belief that "after the Negrosaxon has been made over into the likeness of the white man he can hope to be made into the image of God" (qtd. in Gaines 104).

Fisher's interrogation of white primitivism is also embodied in his parodic satire of Freud, whose theories of primitivism inform the intellectual sources of modernism. For Nathan Huggins, three factors shape the (white) modernist obsession with primitivism: the discovery of African art by European intellectuals, the disenchantment with Western civilization as a result of the First World War, and the popularization of Freud. And while each factor capitalized on the primitive and romantic, Huggins sees oversimplification of the concepts of id and super-ego as investing primitivism with the capacity to meet psychological needs of "soft rebellion." As Huggins explains,
White Americans had identities of their own to find, and black men were too essential to them to be ignored. Men who sensed that they were slaves to moral codes, that they were cramped, and confined by guilt-producing norms which threatened to make them emotional cripples, found Harlem a tonic and a release. Harlem Negroes' lives appeared immediate and honest. Everything they did-their music, their art, their dance-uncoiled deep inner tensions. Harlem seemed a cultural enclave that had magically survived the psychic fetters of Puritanism. (89)

One of the ways in which Fisher parodies Freud is with the rite of the gonad, which satirizes theories of primitivism as the quintessential id attributed to blacks as a "race." The germplasm contained in the male sex glands Frimbo uses for the "Buwongo secret" is tantamount to such a racial id, containing " 'protoplasm which has been continuously maintained through thousands of generations' " (269).

Archer even reads the ritual in Freudian terms, diagnosing it as " 'part of [Frimbo's] compensatory mechanism" " (291). In terms of style, the parody is in keeping with Fisher's talent for light satire and demonstrates his ability to orchestrate the vernacular of both the scientific and the black communities. When Dart asserts that he believes Frimbo to have killed the servant " 'because he's a nut,'" Archer' responds,

\footnotetext{
"Please-not so bluntly. It sounds crude-robbed of its nuances and subtleties. You transform a portrait into a cartoon. Say, rather, that under the influence of certain compulsions, associated with a rather intricate psychosis, he was impelled to dispose of his servant for definite reasons." (290)
}

In their endorsement of Frimbo's Africanity, Soitos and Lock fail to recognize that the "unbroken heritage of the past" embodied in the rite of the gonad is available only to privileged men. As the "epitome of the past," the rite of the gonad " 'goes back in a continuous line to the remotest origins of the organism.' "Moreover, as the sole authority who can bring " into the pre- 
sent every influence which the past has implanted upon life" " (269), Frimbo becomes the monolithic voice of that text. From a liminal perspective, Frimbo's death, and with it that of the "Buwongo secret," becomes more complex than a symbolic defeat in a binary cultural struggle.

At the same time, as a scientist and man of modern sensibilities, Fisher recognizes valid aspects of Freudian theory, particularly in terms of the pathological effects of the binary cultural struggle. As Archer explains to Dart, Frimbo's "intricate psychosis' " is the result of a paranoiac delusion of persecution. And while Dart, ever the voice of pragmatism, points out that part of being black in America is learning to negotiate such "persecution," it is clear that, because of his privileged status, Frimbo has had no cause to temper expectations. As Archer explains, episodes of racial discrimination produce in Frimbo a bitterness even "'more acute in one accustomed to absolute authority and domination' " (229). While Lock cites Frimbo's declaration to Archer-" 'You are almost white. I am almost black. Find out why, and you will have solved a mystery' " (230)—as evidence of Archer's world view as "white" (46), Archer is the character whose education has been financed by struggle, first by his father's and then by his own. In fact, far from being the embodiment of a "white" world view (Lock 46), Archer is the character who has overcome the obstacles faced by black professionals, a fact not lost on Frimbo. Assessing the "drama" about which Archer is reticent, Frimbo concludes: " 'If drama is struggle, my friend, your life is a perfect play'" (225). As one who has experienced struggle, it is Archer who is sympathetic to Frimbo, finding it both curious and understandable that Frimbo's reaction to racial prejudice is a " 'flight into study ... steeped in deterministic philosophy" " (259). s I argue here, The Conjure-

Man Dies crystallizes a moment of literary and cultural liminality, a moment made possible because Rudolph Fisher was both a Harlem Renaissance and a black modernist writer fully participating in the multicultural Zeitgeist of American modernism. As a modernist text, The Conjure-Man Dies demonstrates that the Zeitgeist shaping the Harlem Renaissance was both the same as and different from the Zeitgeist shaping Euro-American modernism, in that the work not only absorbs the modernist discourse of white primitivism but also critiques the ideology of racial uplift and black nationalism, the liminal constructs in the black community against which black modernists reacted. And although the larger mystery in The Conjure-Man Dies is generally acknowledged by critics as Frimbo's statement that "the rest of the world would do better to concern itself with why Frimbo was black,' " my reading suggests that the larger mystery lies in why Frimbo was killed.

As a moment of cultural liminality, Frimbo's death enables Fisher symbolically to destroy the impulse toward authoritarianism and rational individualism embodied in racial uplift and black nationalism. At the same time, Frimbo's imposing character counters images of the cult of white primitivism to convey positive images of Africa as a culture, a concern fundamental to both generations of black intellectuals. As a moment of literary liminality, Frimbo's death enables Fisher to reject the monolithic voice of Eurocentric classical detection by destroying the genre's most recognizable symbol. The device of making the "calculable" mystery of lesser importance opens the Afrocentric story of detection to indeterminant mystery, ${ }^{7}$ while the narrative strategy of giving the last words to Bubber, the street-smart detective, sets the stage for Chester Himes and the hard-boiled detective tradition. Finally, 
as a response to Alain Locke's challenge that younger artists explore folk material as the basis of a black art that moves toward "pure art," toward writing that was "racial... purely for the sake of art" (51), Fisher, in The

Conjure-Man Dies, uses race as art and art as part of the "large responsibility" of shaping black American culture from an autonomous black perspective.

Notes 1. The first non-serialized detective novel by an African American is The Haunting Hand (1926) by Walter Adolphe Roberts, whose detective Frankie Y. Bailey calls "a spunky young white woman" who solves crimes by intuition (53). The only black character in the novel is a maid who makes "two brief, barely visible appearances" (Bailey 53). Arguably, Wilkie Collins's The Moonstone (1868) is the first novel to use multiple detectives in its strategy to incorporate what John Cawelti identifies as a "variety of narrators and a number of inquiring protagonists who play the role of detective at various phases of the inquiry" (134). Nonetheless, as Cawelti notes, The Moonstone, though one of the first novels to present a professional detective, is ultimately a gothic melodrama whose characteristics place it "between the nineteenth-century novel of sensation and the twentieth-century classical detective story" (135).

2. Of all the black modernists, Fisher's qualifications are perhaps the most impressive: A graduate of public schools in Providence, Rhode Island, Fisher attended Brown University, where he excelled in biology and English, as well as Latin, public speaking, and military engineering. By his graduation in 1919, Fisher had been elected to three honor fraternities, including Phi Beta Kappa, and as commencement speaker he delivered a paper on "The Emancipation of Science," which John McCluskey describes as painting "in broad strokes the birth pangs of modernity" (xiv). After receiving his first post-baccalaureate degree from Brown, Fisher attended Howard University Medical School, taking courses in roentgenology and graduating with highest honors in a class of twenty-seven. Awarded a National Research Council Fellowship in 1925, Fisher conducted research in bacteriology at the College of Physicians and Surgeons, Columbia University, and co-authored an article published in the Journal of Infectious Diseases. His research led to work at the Bronx and Mt. Sinai Hospitals in New York. In 1930, by then in private practice, Fisher was elected Head of the Department of Roentgenology at International Hospital in Jamaica.

3. Nonetheless, as Gaines points out, the black modernists' "bold foray into racial expression was not without problematic baggage of authenticity and primitivism" (249). Jean Toomer's Cane, for example, shares the devolutionary tendencies of academic folklore, while Claude McKay's Home to Harlem is generally seen as capitalizing on the market of white primitivism discovered by Van Vechten's Nigger Heaven. Like Hughes's success in negotiating these dangers, Fisher's is acknowledged by African American literary critics (see Huggins, Bell), while his ability to manipulate the black vernacular comprises the bulk of the criticism of his work.

4. See Charles Chesnutt's The Marrow of Tradition (1901) for one of the most comprehensive accounts of retrogression in African American fiction.

5. See also Adell.

6. While Gaines admits that assimilationists such as Ferris may not seem radical in comparison to black nationalists of the 1970s, he finds Ferris's "epic" chronicle The African Abroad, or His Evolution in Western Civilization, Tracing His Development under Caucasian Milieu, written between 1902 and 1913 , valuable in its insight into the growing aversion to Washington as a spokesman for the race.

7. In an article not yet published, I apply Lock's notion of the indeterminacy inherent in the Osiris myth to The Conjure-Man Dies and analyze ways in which this change in mythological models alters the fundamental structure of the classical detective pattern.

Adell, Sandra. Double Consciousness/Double Bind: Theoretical Issues in Twentieth-Century Black Literature. Urbana: $U$ of Illinois P, 1994.

Bailey, Frankie Y. Out of the Woodpile: Black Characters in Crime and Detective Fiction. New York: Greenwood P, 1991.

Bell, Bernard. The Afro-American Novel and Its Tradition. Amherst: U of Massachusetts P. 1987. Carby, Hazel. Reconstructing Womanhood: The Emergence of the Afro-American Woman Novelist. New York: Oxford UP, 1987. 
Cawelti, John. Adventure, Mystery, and Romance: Formula Stories as Art and Popular Culture. Chicago: $U$ of Chicago P. 1976.

Davis, Arthur. "Harlem Mysterious." Opportunity Oct. 1932: 320.

Du Bois, W. E. B.. The Souls of Black Folk. 1903. New York: Bantam, 1989.

Fisher, Rudolph. The Conjure-Man Dies. 1932. Ann Arbor: U of Michigan P, 1992.

Gaines, Kevin. Uplifting the Race: Black Leadership, Politics, and Culture in the Twentieth Century. Chapel Hill: $U$ of North Carolina P, 1996.

Gates, Henry Louis; Jr. "Authority, (White) Power, and the (Black) Critic; It's All Greek to Me." The Nature of Minority Discourse. Ed. Abdul R. Mohamed and David Lloyd. New York: Oxford UP, 1990. 72-101.

Gilroy, Paul. The Black Atlantic: Modernity and Double Consciousness. Cambridge: Harvard UP, 1993.

Grella, George. "Murder and Manners: The Formal Detective Novel." Novel 4 (1970): 30-48.

Howe, Irving. The Idea of the Modern. New York: Horizon P, 1967.

Huggins, Nathan. Harlem Renaissance. New York: Oxford UP, 1971.

Lewis, David Levering: When Harlem Was In Vogue. New York: Oxford UP, 1979.

Lock, Helen. A Case of Mis-Taken Identity: Detective Undercurrents in Recent African-American Fiction. New York: Peter Lang, 1994.

Locke, Alain. "The New Negro." The New Negro. 1925. Ed. Locke. New York: Atheneum, 1968. 3-16.

Kent, George. Blackness and the Adventure of Western Culture. Chicago: Third World P, 1972.

Knight, Stephen. Form and Ideology in Crime Fiction. Bloomington: Indiana UP, 1980.

McCluskey, John, ed. City of Refuge: The Collected Stories of Rudolph Fisher. Columbia: $U$ of Missouri P, 1987.

Soitos, Stephen. The Blues Detective: A Study of African American Detective Fiction. Amherst: $U$ of Massachusetts P, 1996.

Stoff, Michael B. "Claude McKay and the Cult of Primitivism." The Harlem Renaissance Remembered. Ed. Arna Bontemps. New York: Dadd, Mead, 1972. 126-46.

Tate, Claudia. Domestic Allegories of Political Desire: The Black Heroine's Text at the Turn of the Century. New York: Oxford UP, 1992.

Tignor, Eleanor Q. "Rudolph Fisher: Harlem Novelist." Langston Hughes Review 2 (Fall 1982): 13-22

Tracy, Steven C. Langston Hughes and the Blues. Urbana: U of Illinois P. 1988.

Worth, Robert. "Nigger Heaven and the Harlem Renaissance." African American Review 29 (1996): 461-73.

Wright, Austin. The Formal Principle in the Novel. Ithaca: Cornell UP, 1982.

\section{Position Notice: English Instructor Central Piedmont Community College, Charlotte, NC}

This replacement position in the English, Literature, and Languages Division (contingent upon final budget approval) requires a master's degree with 18 graduate semester hours in English. Applicants should subscribe to the community college mission and demonstrate both computer literacy and ability to deal with a diverse student population. Additionally, candidates should be qualified to teach humanities and world literature, as well as firstyear college writing classes.

CPCC, a large, urban community college with two suburban campuses, offers AA, AS, and AAS degrees, as well as certificate and diploma programs. CPCC emphasizes excellence in teaching and encourages faculty to participate in college, professional, and community activities.

Located in the southern Piedmont region of North Carolina, Charlotte is the state's largest city, poised for continued dynamic growth.

For a job description and application, contact Steven B. McClure, Director of Personnel Services CPCC, P.O. Box 35009, Charlotte, NC 28235-5009 (704) 330-6631

CPCC is an equal opportunity institution. 